\title{
Geochemistry and Petrogenesis of Granitoids from Kameng Corridor of Arunachal Himalaya, Northeast India
}

\author{
Santosh Kumar* and Manjari Pathak \\ Department of Geology, Kumaun University, Nainital 263 002, Uttrarakhand, INDIA \\ * For correspondence, email: skyadavan@yahoo.com
}

Felsic magmatisms in Kameng Corridor of Arunachal Himalaya are mainly represented by extensively exposed Palaeoproterozoic granite gneiss (GGn), small stock-like undeformed Mesoproterozoic biotite granite (BG) and veins and pods of Tertiary leucogranite (TLg). The magnetic susceptibility (MS) measurements and whole rock geochemistry of these felsic magmatic bodies have been carried out in order to evaluate nature of granite series and petrogenesis of these felsic rocks with its implication on collisional tectonics.

The GGn records average MS of $0.243 \times 10^{-3} \mathrm{SI}$ at Bomdila proper corresponding to ilmenite series (reduced type) granites, which further reduced $\left(\chi=0.076 \times 10^{-3} \mathrm{SI}\right)$ in close contact with black shales of Salari Group. The BG measures MS values between 0.156 and $0.120 \times 10^{-3}$ SI slightly changing from core to margin of the stock suggesting marginal reduction of BG melt at emplacement level. The TLg bears MS values $(\chi=0.042$ to $\left.2.82 \times 10^{-3} \mathrm{SI}\right)$ and at places intrudes the hornblende-biotite granite $\left(\chi=15.42-27.37 \times 10^{-3} \mathrm{SI}\right)$ an older lithounit of Sela Group exposed beyond the Main Crystalline Thrust (MCT). Observed MS variations of these felsic magma bodies appear primarily intrinsic to crustal (metasedimentary) source regions, although these melts have been partly reduced at emplacement level as a result of reaction with carbonaceous country rocks.

The modal composition of GGn represents largely monzogranite (ss) whereas BG corresponds to granodiorite, which are related to pre-Himalayan syncollisional and pre-plate collisional tectonics respectively. However, the TLg is ms-bt \pm tur leucogranite corresponding to peraluminous syncollisional (Himalayan) anatectic melt. Muscovite of GGn represents solidsolution of celadonitic and paragonitic end-members of primary muscovite composition. Empirically estimated Li-content of GGn muscovite relates to Li-mica zinnwaldite. Biotite in GGn is mostly transitional between $\mathrm{Fe}$ - and $\mathrm{Mg}$-biotites evolved from FMQ to NNO buffers syn-crystallizing with muscovite, and exhibits dominant $\mathrm{Mg} \rightleftharpoons \mathrm{Fe}$ and less pronounced $2 \mathrm{Al} \rightleftharpoons 3 \mathrm{Fe}^{2+}$ substitutions typical to its evolution in a peraluminous (S-type) felsic melt. Biotite in BG is, however, ferribiotite evolved from FMQ to NNO buffers and exhibits pronounced $\mathrm{Mg} \rightleftharpoons \mathrm{Fe}$ and less pronounced $3 \mathrm{Mg} \rightleftharpoons 2 \mathrm{Al}$ substitutions typical to its crystallization in a calc-alkaline, metaluminous (I-type) felsic melt. GGn biotite is markedly enriched in siderophyllite and depleted in phlogopite components as compared to BG biotite. Tourmaline from GGn belongs to schorl $(\mathrm{Fe})$-dravite $(\mathrm{Mg})$-elbaite $(\mathrm{Li}+\mathrm{Al})$ end-members solid-solution typically crystallized in a Li-poor felsic melt. Whole rock composition of GGn (molar A/CNK= 1.19-1.45) and TLg (molar $\mathrm{A} / \mathrm{CNK}=1.29-1.33$ ) represents typical to peraluminous (S-type) granites whereas BG (molar A/ $\mathrm{CNK}=0.95-0.97$ ) is metaluminous (I-type) in character, strongly suggesting involvement of heterogeneous protoliths in their genesis. Comparison of melts generated by melting experiments of various protoliths suggests that GGn melts might have been generated by melting of biotite-rich metapelites whereas BG melt might have been formed from melting of biotite-rich metapelite and/or plagioclase-rich metagrewacke sources. However, the TLg melt appears formed by melting of muscovite-rich metapelite source. These felsic melts are slightly to strongly reduced-type mostly intrinsic to crustal source regions, but most likely formed in diversed tectonic regimes (pre-plate to syn-collisional). Content of $\mathrm{MgO}, \mathrm{Fe}_{2} \mathrm{O}_{3} \mathrm{t}, \mathrm{MnO}, \mathrm{CaO}, \mathrm{K}_{2} \mathrm{O}, \mathrm{Al}_{2} \mathrm{O}_{3}, \mathrm{Sr}, \mathrm{Nb}, \mathrm{Ba}$ decreases with increasing $\mathrm{SiO}_{2}$ content of $\mathrm{GGn}$, showing their compatible nature because of fractional differentiation process mainly involving biotite, plagioclase and K-feldspar. This is further evident by varying degrees of negative Eu-anomalies $\left(\mathrm{EuN} / \mathrm{Eu}^{\star}=0.29-0.47\right), \mathrm{LaN} / \mathrm{LuN}=5.7-14.8$, and sum of rare earth elements $\left(\sum \mathrm{REE}=67-209 \mathrm{ppm}\right)$. However, trace elements characteristics $(\mathrm{Y}=1.06-1.56 \mathrm{ppm}, \mathrm{Yb}=16-19 \mathrm{ppm}, \mathrm{Sr} / \mathrm{Y}=14-35$, $\mathrm{La} / \mathrm{Nb}=1.7-3.0, \mathrm{La} / \mathrm{Yb}=25-43, \mathrm{Zr} / \mathrm{Sm}=34-44)$ and $\mathrm{REE}$ patterns $\left(\mathrm{La}_{\mathrm{N}} / \mathrm{Lu}_{\mathrm{N}}=17-30, \mathrm{Eu}_{\mathrm{N}} / \mathrm{Eu}^{\star}=0.63-0.75\right)$ of $\mathrm{BG}$ appear more like an adakite-like melt but partly contains features similar to a classic arc type calc-alkaline componets. 